\title{
U-values of school building envelopes in the south region of the Federation of Bosnia and Herzegovina
}

\author{
Dragan Katić \\ University of Mostar, Faculty of Civil Engineering \\ M.Sc., dragan.katic@gf.sum.ba \\ Hrvoje Krstić \\ Josip Juraj Strossmayer University of Osijek, Faculty of Civil Engineering and Architecture \\ Ph.D C.E., hrvoje.krstic@gfos.hr \\ Saša Marenjak \\ Josip Juraj Strossmayer University of Osijek, Faculty of Civil Engineering and Architecture \\ Ph.D C.E., sasa@pppcentar.com
}

\begin{abstract}
This paper presents the results of statistical analysis of collected data on the characteristics of envelope elements, as one of the key factors influencing energy consumption and costs, of school buildings (primary and secondary schools) located in the south region of the Federation of Bosnia and Herzegovina (SR FBiH). The shares of the areas of walls, floors, ceilings and openings in the total area of the envelope, as well as thermal characteristics expressed through the heat transfer coefficient or U-value, were analyzed. This research was conducted by collecting data from detailed energy audit documents on a sample of 47 school buildings located in $\mathrm{SR} \mathrm{FBiH}$, which has a Mediterranean or sub-Mediterranean climate. The average envelope U-value is $1.88 \mathrm{~W} / \mathrm{m} 2 \mathrm{~K}$, and the results of this study indicate very poor thermal characteristics of the existing condition of individual elements of the envelope, expressed by $U$-values, which are several times higher than the allowable values.
\end{abstract}

Key words: school buildings, envelope characteristics, U-value, construction period, statistical analysis

\section{U vrijednosti ovojnice školskih zgrada u regiji jug Federacije Bosne i Hercegovine}

Sažetak: U ovom radu prikazani su rezultati statističke analize prikupljenih podataka o karakteristikama elemenata ovojnice, kao jednog od ključnih faktora koji utječu na potrošnju i troškove uporabe energije, školskih zgrada (osnovne i srednje škole) smještenih u regiji jug Federacije Bosne i Hercegovine (RJ FBiH). Analizirani su udjeli površina zidova, podova, stropova i otvora u ukupnoj površini ovojnice kao i toplinske karakteristike izražene preko koeficijenta prolaska topline ili $U$ vrijednosti. Ovo istraživanje je provedeno prikupljanjem podataka iz dokumenata detaljnih energetskih pregleda na uzorku od 47 školskih zgrada smještenih u RJ FBiH koja ima mediteransku ili submediteransku klimu. Prosječna U vrijednost ovojnice iznosi $1,88 \mathrm{~W} / \mathrm{m}^{2} \mathrm{~K}$, a rezultati ovog istraživanja ukazuju na jako loše toplinske karakteristike postojećeg stanja pojedinih elemenata ovojnice, iskazane preko $U$ vrijednosti, koji su nekoliko puta veće od dopuštenih vrijednosti.

Ključne riječi: školske zgrade, karakteristike ovojnice, U vrijednost, razdoblje izgradnje, statistička analiza 
Katić, D., Krstić, H., Marenjak, S.

U-values of school building envelopes in the south region of the Federation of Bosnia an Herzegovina

\section{INTRODUCTION}

Among all public buildings, school buildings have a great social responsibility due to their educational purpose. That is why the energy characteristics of these buildings are of great importance, along with the appropriate levels of indoor environmental quality [1]. Thermal comfort is an important prerequisite in schools. When the thermal satisfaction of the building user is achieved, it is said that the thermal comfort is achieved [2]. Thermal comfort, among other things, cannot be achieved without a quality and satisfactory thermal envelope of the building.

Since children spend about $25 \%$ of their time learning in classrooms, school buildings are to some extent a second home. It is of vital importance to have an indoor climate that will not affect students' comfort, health, or intellectual performance. Research shows that children's examination results decrease in proportion to the increase in complaints with regard to factors such as thermal comfort, indoor air quality, visual and auditory environment [3].

In many European countries, educational buildings like schools share many similar construction, use and maintenance characteristics as well as the frequent feature of high energy consumption. Despite climatic differences throughout Europe, all school buildings are primarily designed to meet winter conditions, so in order to reduce energy consumption, measures on improving thermal properties of the existing envelope are predominantly taken [4].

Buildings use energy throughout their life cycle. Energy is used for construction, use, reconstruction and demolition of structures and as indirect energy it is used for production of materials [5]. For the total life cycle of buildings, the greatest environmental impacts are most dominant in the stage of use due to the energy consumption that represents approximately $80-90 \%$ of the total energy consumption during the life cycle [6].

The amount of energy consumed depends on the technical characteristics of the building itself (thermal characteristics of the envelope elements), efficiency of installed equipment and devices, and behavior of users themselves. Current trends in construction are focused on the implementation of strategies, plans and measures covered by the concept of energy efficiency.

The European building sector still offers great potentials for savings, which are only superficially used. About $75 \%$ of buildings are energy inefficient, and with a current renovation rate of $1 \%$ per year, it would take about a century to decarbonize buildings to modern, low-carbon levels [7].

The characteristics of the building envelope (foundations, roof, walls, doors and windows) and the operating time of the heating system are the factors that have the greatest influence on the total energy consumption. Variables that also have influence on thermal needs of a buildings related to the building shape are the compactness index, shape factor and climate [8]. The building envelope is the most effective indicator of energy consumption used for heating, cooling and ventilation of buildings. Due to the direct interaction with external environmental conditions, the building envelope is defined as the interface of energy loss [4].

Of all the parameters, the most important indicator used to describe the thermal properties of buildings, and thereby the overall energy efficiency of a building, is the heat transfer or thermal transmittance coefficient (U-value) [9]. Studies show that the U-value determines heat loss through a unit area of opaque or transparent parts of the building envelope and that the U-value of building envelope should be determined depending on the building shape defined by the ratio of total envelope area to building volume [10]. 
Katić, D., Krstić, H., Marenjak, S.

U-values of school building envelopes in the south region of the Federation of Bosnia an Herzegovina

This paper is part of a wider research aimed at collecting and analyzing data on the characteristics, consumption and cost of energy used in school buildings in $\mathrm{FBiH}$, as exceptionally important social and public buildings, and determining the relationship between energy performance of buildings and the cost of their use. School buildings in this research include school sports halls (if they exist next to school buildings) which in terms of function and common technical systems (heating, ventilation, air conditioning, electrical installations) make up a whole and thus common energy consumption.

\section{COLLECTION OF RESEARCH DATA}

\subsection{Data from the typology of public buildings of Bosnia and Herzegovina}

The typology of residential buildings, in which systematization of all residential buildings in $\mathrm{BiH}$ was carried out, was developed in Bosnia and Herzegovina in 2016, while the typology of public buildings in Bosnia and Herzegovina (hereinafter TPB BiH) was completed in 2018 and represents the classification and systematization of all public buildings in $\mathrm{BiH}$. TPB $\mathrm{BiH}$ comprise a typological classification matrix with a total of 42 types, i.e. with 6 construction periods and 7 use sectors.

According to the purpose of the buildings, 7 sectors/ types of buildings are defined, namely buildings for preschool education, buildings intended for education, buildings in the health sector, buildings for sports activities, buildings for cultural activities, buildings for administrative activities and buildings for all-day stay which includes hospitals and other buildings intended for all-day stay [11].

The second classification was made in terms of the construction period. Different construction periods have different characteristics of building elements of the envelope, different construction technologies and emergence of new construction materials. Also, the legislation related to thermal protection was changing over time, and was making the requirements stricter, which resulted in changes with regard to their thermal protection. The defined construction periods are until 1945, from 1946 to 1965, from 1966 to 1973, from 1974 to 1987, from 1988 to 2009, and after 2010 [11]. The basic characteristics of buildings are given for each period in TPB BiH, which will not be specified in this paper.

TPB $\mathrm{BiH}$ defines several variables that best define the characteristics of individual buildings and types, and can be considered as character variables. These are the floor area of the building $\left(A_{k}\right)$, the building envelope area $(A)$, the volume of heated air $\left(V_{e}\right)$, the building shape factor $\left(f_{o}\right)$ and the average heat transfer coefficient of the envelope $(U)$ shown in Table 1 together with the total number of buildings intended for education in $\mathrm{FBiH}$ [11].

According to TPB $\mathrm{BiH}$, the largest number of buildings in $\mathrm{FBiH}$ is related to the buildings intended for administrative activities (buildings with office space in various sectors) with a share of $35.7 \%$, followed by the buildings intended for education (primary and secondary schools, faculties and other educational institutions) with a share of $32.9 \%$.

In terms of floor area $\left(A_{k}\right)$, the largest floor area is related to the buildings intended for education with a share of $33.5 \%$, followed by the buildings for administrative activities with a share of $27.7 \%$.

The total number of buildings in $\mathrm{FBiH}$ was also divided into climate regions "north" and "south" which are related to climatological characteristics of locations which as a factor have a great impact on energy consumption. The division is made in relation to the mean monthly temperature of the coldest month of the year and if it is less than $3.0^{\circ} \mathrm{C}$ then the location belongs to the "north" region (abbreviation $\mathrm{NR} \mathrm{FBiH),} \mathrm{or} \mathrm{if} \mathrm{the} \mathrm{mean} \mathrm{monthly} \mathrm{temperature} \mathrm{of}$ the coldest month is higher than $3.0^{\circ} \mathrm{C}$ then the location belongs to the "south" region (abbreviation $\mathrm{SR} \mathrm{FBiH}$ ). With regard to climate regions, the largest number of schools is 
Katić, D., Krstić, H., Marenjak, S.

U-values of school building envelopes in the south region of the Federation of Bosnia an Herzegovina

located in the climate region "north", approximately $81.9 \%(1.192 / 1.455)$ and approximately $18.1 \%(263 / 1,455)$ in the climate region "south".

Table 1. Number of buildings and average values of floor area $\left(A_{k}\right)$, heated air volume $\left(V_{e}\right)$, envelope area $(A)$, building shape factor $\left(f_{o}\right)$ and envelope heat transfer coefficient $(U)$ for school buildings in $\mathrm{FBiH}$ [11]

\begin{tabular}{|c|c|c|c|c|c|c|}
\hline $\begin{array}{c}\text { SCHOOL BUILDINGS } \\
\text { IN FBiH }\end{array}$ & $\begin{array}{c}\text { Number of } \\
\text { buildings in } \\
\text { FBiH } \\
\text { according to } \\
\text { TPB }\end{array}$ & $\begin{array}{c}\text { Average floor } \\
\text { area } \mathrm{A}_{\mathrm{k}}\left(\mathrm{m}^{2}\right) \\
\text { in } \mathrm{FBiH}\end{array}$ & $\begin{array}{c}\text { Average } \\
\text { volume of } \\
\text { heated air } \mathrm{V}_{\mathrm{e}} \\
\left(\mathrm{m}^{3}\right) \text { in } \mathrm{FBiH}\end{array}$ & $\begin{array}{c}\text { Average } \\
\text { envelope } \\
\text { area } \mathrm{A}\left(\mathrm{m}^{2}\right) \text { in } \\
\mathrm{FBiH}\end{array}$ & $\begin{array}{c}\text { Average } \\
\text { value of form } \\
\text { factor } \mathrm{f}_{0}=\mathrm{A} / \mathrm{V}_{\mathrm{e}} \\
\left(\mathrm{m}^{-1}\right) \text { in } \mathrm{FBiH}\end{array}$ & $\begin{array}{c}\text { Average } \\
\text { U-value of } \\
\text { the envelope } \\
\left(\mathrm{W} / \mathrm{m}^{2} \mathrm{~K}\right) \\
\mathrm{FBiH}\end{array}$ \\
\hline until 1945 & 109 & 964 & 3,540 & 1,899 & 0.54 & 1.66 \\
\hline from 1946 to 1965 & 498 & 937 & 3,134 & 1,870 & 0.60 & 1.81 \\
\hline from 1966 to 1973 & 250 & 1,420 & 4,682 & 2,567 & 0.55 & 1.78 \\
\hline from 1974 to 1987 & 343 & 1,663 & 5,524 & 2,830 & 0.51 & 1.78 \\
\hline from 1988 to 2009 & 212 & 934 & 2,977 & 1,723 & 0.58 & 1.66 \\
\hline after 2010 & 43 & 742 & 2,426 & 1,486 & 0.61 & 1.66 \\
\hline TOTAL: & $\mathbf{1 , 4 5 5}$ & $\mathbf{1 , 1 8 7}$ & $\mathbf{3 , 9 5 0}$ & $\mathbf{2 , 1 8 5}$ & $\mathbf{0 . 5 5}$ & $\mathbf{1 . 7 0}$ \\
\hline
\end{tabular}

\subsection{Collection of data from detailed energy audit documents}

In this paper, the characteristics of the envelope of school buildings in SR FBiH were analyzed in relation to construction period. In order to determine the characteristics of school buildings' envelope elements, the question arises as to how to obtain credible and reliable data, or a sample that will be the basis for collecting data on the characteristics of members of the basic population.

Research shows that existing data sets can generally be categorized according to three main strategies by which data samples are generated or obtained [12]:

- the measurement strategy is the measurement of actual data

- the research strategy collects data samples by interviewing individuals and/or from other databases or sources, and is suitable for quantitative and qualitative data collection

- the simulation strategy is an economic way of generating data.

In order to obtain representative and reliable data, the research strategy by collecting data from detailed energy audit documents will be used for this research. Detailed energy audit (DEA) is a documented procedure carried out in order to determine the energy performance of a building and the degree of fulfillment of this performance in relation to the requirements prescribed by special regulations and contains a proposal of measures for cost-effective improvement of energy performance of the building 13].

Energy audit is the main tool for understanding the energy consumption in buildings and it is an in-depth analysis conducted on the building itself in order to determine the actual characteristics and define possible intervention measures aimed at improving the external envelope and replacing existing technologies in order to reduce fuel and electricity consumption. [14].

Energy audits are conducted by authorized professional persons (who have passed the training program and received authorizations) according to the guidelines prescribed for their preparation. The guidelines for conducting energy audits of buildings provide a common implementation methodology, and the main goal is to determine the energy performance for 
Katić, D., Krstić, H., Marenjak, S.

U-values of school building envelopes in the south region of the Federation of Bosnia an Herzegovina

new or existing buildings, and to make recommendations for increasing energy efficiency. The procedure for conducting a detailed energy audit of a building results in a document that includes, among other things, information on construction characteristics of the envelope in terms of thermal protection [13].

Measurement and research strategies are used when preparing DEA documents, and finally they contain a large set of reliable data. From the viewpoint of this research, the DEA documents contain key data on the construction and thermal characteristics of the building envelope.

A total of 47 DEA documents for school buildings in SR FBiH were collected, which represent the basis for the development of this study. General and geometric data on school buildings, which include data on the year of construction, floor area $\left(A_{k}\right)$ and envelope area (A) were collected and selected for this research from the stated documents.

The collected data on building elements of the envelope in the present condition include data on individual areas of building elements of the envelope and total areas classified into 4 groups (walls, floors, ceilings and openings), and values of heat transfer coefficients (U) of individual building elements and total envelope.

Consistent with this, this research will determine the U-values of heat transfer coefficients for the existing condition and compare them with the allowable values according to the Rules on technical requirements for thermal protection of buildings and rational use of energy [15] in order to determine the degree of fulfillment or satisfaction thereof.

\section{RESEARCH RESULTS}

\subsection{Statistical analysis}

The statistical set or population is represented by statistical units, in this case school buildings in SR FBiH, whose scope and basic characteristics are defined in the TPB BiH document, while the collected DEAs represent the basic statistical sample for collecting data (observed results) on the characteristics of the statistical set or population. A basic statistical analysis (descriptive statistics) was performed.

Table 2. Sample descriptive statistics data of school buildings in SR FBiH from the sample

\begin{tabular}{|l|c|c|c|c|c|c|c|c|}
\hline \multicolumn{1}{|c|}{ Variable } & $n$ & $X_{\min }$ & $X_{\max }$ & $R_{x}$ & $\bar{X}$ & $M_{e}$ & $\sigma_{x}$ & $V$ \\
\hline Year of construction (year) & 47 & 1896 & 2014 & 118 & 1968.5 & 1973.0 & 22.02 & $1.1 \%$ \\
\hline Floor area Ak $\left(\mathrm{m}^{2}\right)$ & 47 & 83.60 & 4435.0 & 4351.4 & 1877.6 & 1724.8 & 1155.2 & $61.5 \%$ \\
\hline Area of walls SR FBiH $\left(\mathrm{m}^{2}\right)$ & 47 & 105.7 & 2420.0 & 2314.3 & 1205.6 & 1099.8 & 624.6 & $51.8 \%$ \\
\hline Area of floors SR FBiH $\left(\mathrm{m}^{2}\right)$ & 47 & 100.1 & 3608.4 & 3508.3 & 1059.7 & 1041.0 & 677.3 & $63.9 \%$ \\
\hline Area of ceilings SR FBiH $\left(\mathrm{m}^{2}\right)$ & 47 & 100.1 & 3773.1 & 3673.0 & 1194.9 & 1192.0 & 734.9 & $61.5 \%$ \\
\hline Area of openings SR FBiH $\left(\mathrm{m}^{2}\right)$ & 47 & 22.0 & 1514.0 & 1492.0 & 484.9 & 455.4 & 327.8 & $67.6 \%$ \\
\hline Envelope area SR FBiH $\left(\mathrm{m}^{2}\right)$ & 47 & 327.9 & 10482.9 & 10155.0 & 3945.2 & 4030.3 & 2189.9 & $55.5 \%$ \\
\hline U-value of walls $\left(\mathrm{W} / \mathrm{m}^{2} \mathrm{~K}\right)$ & 47 & 0.25 & 2.73 & 2.47 & 1.55 & 1.60 & 0.54 & $34.5 \%$ \\
\hline U-value of floors $\left(\mathrm{W} / \mathrm{m}^{2} \mathrm{~K}\right)$ & 47 & 0.34 & 4.18 & 3.84 & 1.89 & 1.65 & 1.13 & $59.7 \%$ \\
\hline U-value of ceilings $\left(\mathrm{W} / \mathrm{m}^{2} \mathrm{~K}\right)$ & 47 & 0.34 & 4.81 & 4.47 & 1.90 & 1.84 & 1.05 & $55.5 \%$ \\
\hline U-value of openings $\left(\mathrm{W} / \mathrm{m}^{2} \mathrm{~K}\right)$ & 47 & 1.41 & 4.29 & 2.88 & 2.76 & 2.91 & 0.65 & $23.6 \%$ \\
\hline Envelope U-value $\left(\mathrm{W} / \mathrm{m}^{2} \mathrm{~K}\right)$ & 47 & 0.51 & 3.09 & 2.59 & 1.88 & 1.88 & 0.61 & $32.5 \%$ \\
\hline
\end{tabular}


Katić, D., Krstić, H., Marenjak, S.

U-values of school building envelopes in the south region of the Federation of Bosnia an Herzegovina

In the statistical analysis, the following symbols were used: $(n)$ is the number of units, ( $\left.x_{\text {min }}\right)$ minimum value, $\left(X_{\max }\right)$ maximum value, $\left(R_{x}\right)$ range of values, $(\bar{X})$ average value, ( $\left.M_{e}\right)$ median, $\left(\sigma_{x}\right)$ standard deviation and $(V)$ coefficient of variation.

Table 2 shows the results of descriptive statistics of the considered variables on the general and geometric characteristics of school buildings, and on thermal characteristics of the envelope elements.

The coefficient of variation $(V)$ is a relative measure of dispersion and represents the ratio of standard deviation to arithmetic mean. Values of up to $10 \%$ represent very low variability, $10 \%$ to $30 \%$ weak, $30 \%$ to $50 \%$ moderate, $50 \%$ to $70 \%$ strong and over $70 \%$ very strong variability (indicating that the distribution is not uniform). A smaller measure of dispersion means a higher representativeness of the mean and vice versa $[16,17]$.

The task of descriptive statistics is to describe, organize and summarize the research results in order to make them clearer, more understandable and more suitable for interpretation and further analysis [17]. The summarized results of the statistical analysis of the data from the sample in this part of the paper are presented tabularly in Table 3 and graphically in the form of histograms in Figures 1 and 2.

Table 3. Data on the number of buildings and floor areas $\left(A_{k}\right)$ of school buildings in SR FBiH according to TPB and from the sample with respect to construction period

\begin{tabular}{|c|c|c|c|c|c|c|}
\hline $\begin{array}{l}\text { SCHOOL } \\
\text { BUILDINGS IN SR } \\
\text { FBiH }\end{array}$ & $\begin{array}{c}\text { Number } \\
\text { of } \\
\text { buildings } \\
\text { in SR } \\
\text { FBiH } \\
\text { according } \\
\text { to TPB }\end{array}$ & $\begin{array}{c}\text { Number } \\
\text { of } \\
\text { buildings } \\
\text { in SR } \\
\text { FBiH } \\
\text { from the } \\
\text { sample }\end{array}$ & $\begin{array}{c}\text { Share (\%) of } \\
\text { the number of } \\
\text { buildings from } \\
\text { the sample to } \\
\text { the total } \\
\text { number of } \\
\text { buildings of } \\
\text { TPB }\end{array}$ & $\begin{array}{c}\text { Total floor } \\
\text { area Ak }\left(\mathrm{m}^{2}\right) \\
\text { in SR FBiH } \\
\text { according to } \\
\text { TPB }\end{array}$ & $\begin{array}{c}\text { Total floor } \\
\text { area } A_{k}\left(\mathrm{~m}^{2}\right) \\
\text { SR FBiH } \\
\text { from the } \\
\text { sample }\end{array}$ & $\begin{array}{c}\text { Share (\%) of } \\
\text { the area } A_{k} \\
\text { from the } \\
\text { sample to the } \\
\text { total area of } \\
\text { TPB }\end{array}$ \\
\hline until 1945 & 20 & 4 & $20.0 \%$ & 19,282 & 4,626 & $24.0 \%$ \\
\hline from 1946 to 1965 & 90 & 13 & $14.4 \%$ & 84,302 & 23,119 & $27.4 \%$ \\
\hline from 1966 to 1973 & 45 & 8 & $17.8 \%$ & 63,908 & 12,646 & $19.8 \%$ \\
\hline from 1974 to 1987 & 62 & 17 & $27.4 \%$ & 103,078 & 40,008 & $38.8 \%$ \\
\hline from 1988 to 2009 & 38 & 4 & $10.5 \%$ & 35,503 & 3,820 & $10.8 \%$ \\
\hline after 2010 & 8 & 1 & $12.5 \%$ & 5,937 & 4,030 & $67.9 \%$ \\
\hline TOTAL: & $\mathbf{2 6 3}$ & $\mathbf{4 7}$ & $\mathbf{1 7 . 9 \%}$ & $\mathbf{3 1 2 , 0 1 0}$ & $\mathbf{8 8 , 2 4 9}$ & $\mathbf{2 8 . 3 \%}$ \\
\hline
\end{tabular}

The size of this statistical sample is 47 school buildings in the south region of $\mathrm{FBiH}$. The share of the number of buildings from this sample in relation to the total statistical set is approximately $17.9 \%(47 / 263)$. The share of the floor area $\left(A_{k}\right)$ from the sample in relation to the total statistical set is approximately $28.3 \%$ (88.249/312.010), which in terms of area represents slightly more than $1 / 4$ of the total statistical set. 
Katić, D., Krstić, H., Marenjak, S.

U-values of school building envelopes in the south region of the Federation of Bosnia an Herzegovina

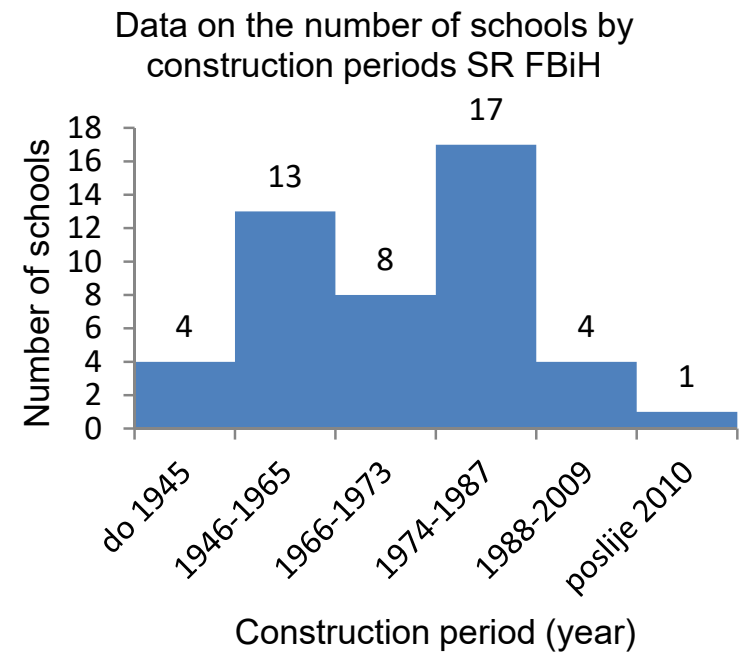

Figure 1. Number of school buildings in $\mathrm{SR} F B i H$ from the sample with respect to construction period and floor area $\left(A_{k}\right)$

From Figure 1 it can be seen that the largest number of analyzed buildings from the sample was constructed in the period from 1974 to 1987, followed by the period from 1946 to 1965. In the construction period after 2010 , there is only one school in the statistical sample.

In terms of construction period, $50 \%$ of school buildings in $\mathrm{SR} \mathrm{FBiH}$ from the sample were constructed in the period from 1961 to 1980 , and 35 schools, or $74.5 \%$ in the period between 1946 and 1988. The average floor area $\left(A_{k}\right)$ of schools together with school halls is approximately $1,878.00 \mathrm{~m} 2$ and is greater than the average floor area according to Table 1 because it also includes the areas of school halls.

\subsection{Analysis of characteristics of the envelope of school buildings}

Some of the parameters or variables that affect thermal energy consumption and on which the costs depend are the composition of the structure (primarily of the envelope) and construction method, climatic conditions and duration of heating season, efficiency of installed systems and installations for space heating, purpose of the building, number of users and heating operation mode, energy source used for heating and its price [18]. New schools show lower energy consumption compared to buildings constructed during the absence of energy regulations [19].

One of the parameters for estimating the energy needs for heating and cooling is the number of degree days (DD). It is assumed that the energy needs for a building are proportional to the difference between the basic temperature and the mean temperature of outdoor air [20]. The average value of heating degree days (HDD) in SR FBiH is 1,759 ${ }^{\circ} \mathrm{C}^{*}$ days.

When collecting and selecting data from the DEA documents, the average areas of building elements of the envelope, categorized into 4 groups (walls, floors, ceilings and openings) were determined. Walls include the surfaces of all external walls (walls facing outside air), walls facing the ground as well as walls facing unheated spaces. Floors are surfaces in contact with the ground, i.e. floors on the ground and floors against unheated 
Katić, D., Krstić, H., Marenjak, S.

U-values of school building envelopes in the south region of the Federation of Bosnia an Herzegovina

basements. Ceilings include ceiling surfaces above heated space against the attic, against flat (passable and impassable) or sloping roofs, ceilings above the outdoor air and ceilings next to unheated spaces. Openings include transparent and opaque elements on the envelope (usually on walls) and consist of windows, doors and skylights. Table 4 summarizes the average areas of building elements of the envelope.

Table 4. Data on average areas of building elements of the envelope of school buildings in $\mathrm{SR} \mathrm{FBiH}$ from the sample with respect to construction period.

\begin{tabular}{|c|c|c|c|c|c|c|c|c|c|}
\hline $\begin{array}{l}\text { SCHOOL } \\
\text { BUILDINGS IN } \\
\text { SR FBiH }\end{array}$ & $\begin{array}{l}\text { Avg. } \\
\text { area of } \\
\text { walls } \\
\left(\mathrm{m}^{2}\right) \text { in } \\
\text { SR } \\
\text { FBiH }\end{array}$ & $\begin{array}{l}\text { Share } \\
\text { (\%) of } \\
\text { the area } \\
\text { of walls } \\
\text { in the } \\
\text { total } \\
\text { envelope } \\
\text { area in } \\
\text { SR } \\
\text { FBiH }\end{array}$ & $\begin{array}{l}\text { Avg. } \\
\text { area of } \\
\text { floors } \\
\left(\mathrm{m}^{2}\right) \text { in } \\
\text { SR } \\
\text { FBiH }\end{array}$ & $\begin{array}{c}\text { Share } \\
\text { (\%) of } \\
\text { the area } \\
\text { of floors } \\
\text { in the } \\
\text { total } \\
\text { envelope } \\
\text { area in } \\
\text { SR } \\
\text { FBiH }\end{array}$ & $\begin{array}{l}\text { Avg. } \\
\text { area of } \\
\text { ceilings } \\
\left(\mathrm{m}^{2}\right) \text { in } \\
\text { SR } \\
\text { FBiH }\end{array}$ & $\begin{array}{c}\text { Share } \\
(\%) \text { of } \\
\text { the area } \\
\text { of } \\
\text { ceilings } \\
\text { in the } \\
\text { total } \\
\text { envelope } \\
\text { area in } \\
\text { SR } \\
\text { FBiH }\end{array}$ & $\begin{array}{l}\text { Avg. } \\
\text { area of } \\
\text { openings } \\
\left(\mathrm{m}^{2}\right) \text { in } \\
\text { SR } \\
\text { FBiH }\end{array}$ & $\begin{array}{c}\text { Share } \\
(\%) \text { of } \\
\text { the area } \\
\text { of } \\
\text { openings } \\
\text { in the } \\
\text { total } \\
\text { envelope } \\
\text { area in } \\
\text { SR } \\
\text { FBiH }\end{array}$ & $\begin{array}{c}\text { Avg. } \\
\text { envelope } \\
\text { area } \\
\left(\mathrm{m}^{2}\right) \text { in } \\
\text { SR } \\
\text { FBiH }\end{array}$ \\
\hline until 1945 & 1,117 & $45.5 \%$ & 541 & $22.0 \%$ & 583 & $23.7 \%$ & 215 & $8.8 \%$ & 2,455 \\
\hline from 1946 to 1965 & 1,185 & $32.4 \%$ & 905 & $24.8 \%$ & 1,053 & $28.8 \%$ & 510 & $14.0 \%$ & 3,654 \\
\hline from 1966 to 1973 & 1,057 & $31.8 \%$ & 871 & $26.2 \%$ & 1,022 & $30.8 \%$ & 373 & $11.2 \%$ & 3,322 \\
\hline from 1974 to 1987 & 1,379 & $27.8 \%$ & 1,409 & $28.4 \%$ & 1,542 & $31.2 \%$ & 628 & $12.7 \%$ & 4,959 \\
\hline from 1988 to 2009 & 662 & $30.2 \%$ & 601 & $27.4 \%$ & 677 & $30.9 \%$ & 250 & $11.4 \%$ & 2,190 \\
\hline after 2010 & 2,236 & $26.4 \%$ & 2,559 & $30.2 \%$ & 3,038 & $35.9 \%$ & 631 & $7.5 \%$ & 8,464 \\
\hline TOTAL & 1,206 & $30.6 \%$ & 1,060 & $26.9 \%$ & 1,195 & $30.3 \%$ & 485 & $12.3 \%$ & 3,945 \\
\hline
\end{tabular}

It can be seen that the share of the area of walls is decreasing and the share of the area of openings and ceilings is increasing for newer and younger schools. Observing the overall sample, the areas of external walls and ceilings account for approximately $30.5 \%$ each, followed by the area of floors with approximately $27 \%$ and finally the area of openings with approximately $12 \%$.

The average area of walls is $1,206.00 \mathrm{~m}^{2}, 35$ schools or $74.5 \%$ are in the range from 500.00 to $2,000.00 \mathrm{~m}^{2}$, and $50 \%$ of wall areas in the sample are in the range from 701.00 to $1,589.00 \mathrm{~m}^{2}$. The average area of floors is $1,060.00 \mathrm{~m}^{2}, 29$ schools or $61.7 \%$ are in the range from 500.00 to $1,500.00 \mathrm{~m}^{2}$. The average area of ceilings is $1,195.00 \mathrm{~m}^{2}, 28$ schools or $59.6 \%$ are in the range from 500.00 to $1,500.00 \mathrm{~m}^{2}$. The average area of openings is 485.00 $\mathrm{m}^{2}$.

Then, data on the characteristics of the building elements of the envelope, which includes the structural composition (layers with material type) and values of calculated heat transfer coefficients $(U)$ expressed in $\mathrm{W} / \mathrm{m}^{2} \mathrm{~K}$, were collected from the DEA documents for each individual building element of the envelope.

Heat passes through the building envelope because of the difference in temperature between the warm air indoor and the cold outdoor air in the direction of the lower temperature. Heat loss cannot be stopped; however, it can be reduced by improving the thermal insulation of the building's outer envelope. The heat transfer coefficient $U$ (U-value) of a building element shows what quantity of heat $(\mathrm{J})$ passes in time unit $(1 \mathrm{~s})$ from the heat source by radiation and convection to the inner surface of the building element, then by conduction through the building element of $1 \mathrm{~m}^{2}$ in area to the outer surface and then by radiation and convection from the outer surface to the outside air if the temperature difference between the indoor and outdoor air is $1 \mathrm{~K}$. 
Katić, D., Krstić, H., Marenjak, S.

U-values of school building envelopes in the south region of the Federation of Bosnia an Herzegovina

Transfer of heat through a structure depends on the installed materials, their thermal conductivity and the thickness of their layers. The sequence of layers in the structure does not have an effect on the heat transfer, it becomes important when it comes to the accumulation of heat and thermal response of the building to changes in thermal relations in the environment. Data on thermal permeability of the building envelope are necessary to quantify losses through it. U-value of the building envelope plays a key role in assessing the thermal performance of the structure [21].

For assessment and calculation of the $U$-value of existing buildings, four approaches are available [22]:

1. assessment based on data obtained from historical analysis of buildings or analogies with similar and identical buildings using specific technical databases

2. assessment based on nominal design data

3. assessment based on actual data obtained by structure identification (sampling method or endoscope)

4. on site using heat flow measurements (Heat Flow Meters - HFM).

Data on U-values of individual elements of the envelope of the buildings from the sample analyzed during preparation of the DEA were obtained by calculations based on data obtained by historical analysis of buildings and construction periods.

Analyzing Table 2 in terms of the U-value $\left(\mathrm{W} / \mathrm{m}^{2} \mathrm{~K}\right)$ of building elements of the envelope (walls, floors, ceilings and openings) of school buildings in SR FBiH from the sample, a moderate to medium dispersion can be observed for the values of walls, openings and the total envelope, while for floors and ceilings there is a strong dispersion, i.e. the distribution is not uniform. This is due to different approaches in the calculation of $U$-values for floors and ceilings which caused the dispersion of these data.

The average $\mathrm{U}$-value for the walls is $1.55 \mathrm{~W} / \mathrm{m}^{2} \mathrm{~K}, 30$ schools or $63.8 \%$ of the schools in the sample are in the range of values from 1.25 to $2.00 \mathrm{~W} / \mathrm{m}^{2} \mathrm{~K}$. U-values for floors have a strong dispersion (coefficient of variation is over $50 \%$ ), the average value is $1.89 \mathrm{~W} / \mathrm{m}^{2} \mathrm{~K}$. Uvalues for ceilings also have a strong dispersion, the average value is $1.90 \mathrm{~W} / \mathrm{m}^{2} \mathrm{~K}$. The largest number of schools (14) has U-values for openings in the range from 2.50 to 3.00 $\mathrm{W} / \mathrm{m}^{2} \mathrm{~K}, 36$ schools or $76.6 \%$ of schools from the sample are in the range of values from 2.00 to $3.50 \mathrm{~W} / \mathrm{m}^{2} \mathrm{~K}$. The average $\mathrm{U}$-value of openings is $2.76 \mathrm{~W} / \mathrm{m}^{2} \mathrm{~K}$.

Data on the number of schools in relation to envelope area $\mathrm{SR} \mathrm{FBiH}$

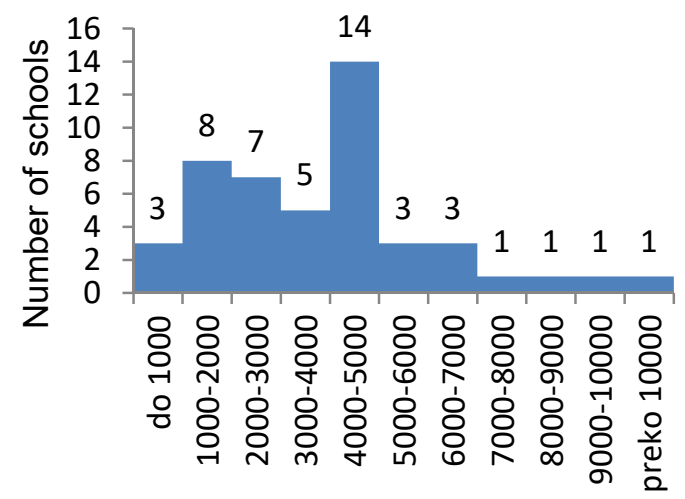

Envelope area $A\left(\mathrm{~m}^{2}\right)$
Data on the number of schools in relation to envelope U-value SR FBiH

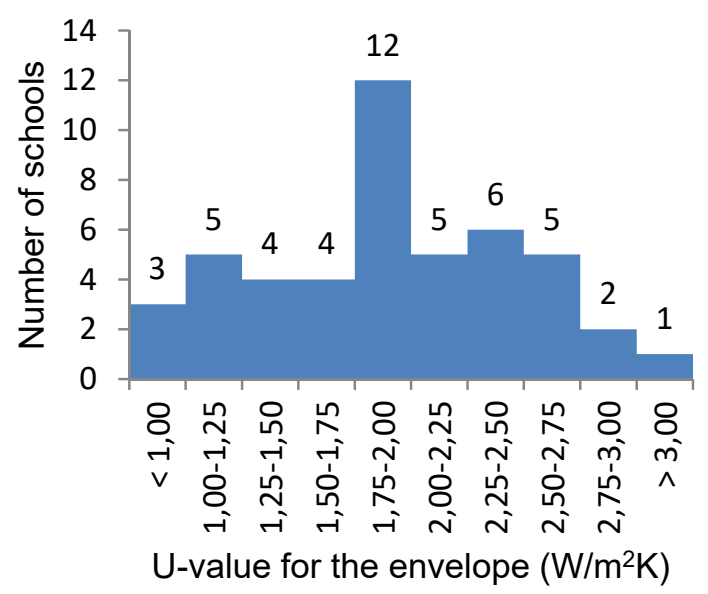

Figure 2. Number of school buildings in $\mathrm{SR} F B i H$ from the sample with respect to construction period versus envelope area and versus $U$-value 
Katić, D., Krstić, H., Marenjak, S.

U-values of school building envelopes in the south region of the Federation of Bosnia an Herzegovina

The average envelope area is $3,945.00 \mathrm{~m}^{2}$ and it is larger than the average envelope area from Table 1, and one of the reasons is the inclusion of the envelope area of school halls. Thirty-four schools or $72.3 \%$ of the envelope areas from the sample are in the range of the envelope area from $1,000.00$ to $5,000.00 \mathrm{~m}^{2}$. The envelope area has a strong data dispersion. The average $\mathrm{U}$-value of the envelope is $1.88 \mathrm{~W} / \mathrm{m}^{2} \mathrm{~K}$ and it is slightly greater than the average $U$-value in Table 1 . The largest number of schools (12) have an average U-value of the envelope in the range from 1.75 to $2.00 \mathrm{~W} / \mathrm{m}^{2} \mathrm{~K}$. U-values of the envelope have a weak to moderate dispersion.

Table 5 summarizes the average U-values of building elements of the envelope. They are obtained based on known individual $U$-values for each individual building element of the envelope and the share of individual areas in the total area of the particular group. The average $U$-values for the entire envelope in relation to construction period are also shown.

Table 5. Average $U$-values of building elements of the envelope of school buildings in SR $\mathrm{FBiH}$ from the sample in relation to construction period

\begin{tabular}{|c|c|c|c|c|c|}
\hline $\begin{array}{l}\text { SCHOOL } \\
\text { BUILDINGS IN SR } \\
\text { FBiH }\end{array}$ & $\begin{array}{c}\text { Average U-value } \\
\left(\mathrm{W} / \mathrm{m}^{2} \mathrm{~K}\right) \text { for walls } \\
\text { in SR FBiH }\end{array}$ & $\begin{array}{c}\text { Average U-value } \\
\left(\mathrm{W} / \mathrm{m}^{2} \mathrm{~K}\right) \text { for } \\
\text { floors in SR FBiH }\end{array}$ & $\begin{array}{c}\text { Average U-value } \\
\left(\mathrm{W} / \mathrm{m}^{2} \mathrm{~K}\right) \text { for } \\
\text { ceilings in SR } \\
\mathrm{FBiH}\end{array}$ & $\begin{array}{c}\text { Average U-value } \\
\left(\mathrm{W} / \mathrm{m}^{2} \mathrm{~K}\right) \text { for } \\
\text { openings in SR } \\
\mathrm{FBiH}\end{array}$ & $\begin{array}{c}\text { Average U-value } \\
\text { of the envelope } \\
\left(\mathrm{W} / \mathrm{m}^{2} \mathrm{~K}\right) \text { in SR } \\
\mathrm{FBiH}\end{array}$ \\
\hline until 1945 & 1.63 & 1.43 & 1.93 & 3.06 & $\mathbf{1 . 8 0}$ \\
\hline from 1946 to 1965 & 1.71 & 2.32 & 2.58 & 2.91 & $\mathbf{2 . 2 7}$ \\
\hline from 1966 to 1973 & 1.57 & 1.75 & 2.07 & 2.73 & $\mathbf{1 . 8 9}$ \\
\hline from 1974 to 1987 & 1.61 & 1.93 & 1.68 & 2.69 & $\mathbf{1 . 8 3}$ \\
\hline from 1988 to 2009 & 1.01 & 1.37 & 0.61 & 2.64 & $\mathbf{1 . 2 5}$ \\
\hline after 2010 & 0.33 & 0.63 & 0.34 & 1.46 & $\mathbf{0 . 5 1}$ \\
\hline TOTAL & $\mathbf{1 . 5 5}$ & $\mathbf{1 . 8 9}$ & $\mathbf{1 . 9 0}$ & $\mathbf{2 . 7 6}$ & $\mathbf{1 . 8 8}$ \\
\hline
\end{tabular}

Analyzing the change in the values of average $U$-values for walls by construction periods, the influence of the change in wall thickness can be observed. Buildings constructed before 1945 have massive external walls made of $48 \mathrm{~cm}$ thick solid brick or of natural stone and plastered on both sides. After this period, there was a change in construction technologies and introduction of reinforced concrete so that walls became thinner, which led to an increase in the U-value for walls. A decrease in the $U$-value of walls began from the end of the 1980s and the beginning of use of thermal insulation layers in the structure of walls.

The U-value of openings did not begin to significantly improve until after 2010 . Openings have poor thermal characteristics and high air permeability. A low U-value of windows is a good option since it reduces the need for heating, while it does not have much influence on the need for cooling [23].

The construction period until 1945 is characterized by traditional construction techniques without the use of thermal protection. The materials used were mainly intended to satisfy the load-bearing capacity needs while the thermal protection of the buildings was not applied. Exterior massive walls were mainly built of brick or stone. The floor structures were mainly made of wood, or were massive made of brick or stone, and sometimes (in the later part of this period) of ribbed concrete. Basements rooms in these buildings are mostly unheated spaces with massive walls, the purpose of which was in a way to separate the living space from the ground. The ceilings against unheated space (attic) are usually made of wood with 
Katić, D., Krstić, H., Marenjak, S.

$\mathrm{U}$-values of school building envelopes in the south region of the Federation of Bosnia an Herzegovina

boarding on both sides and interspace filled with rubble. Windows and doors were wooden with a single glass pane, or double with two casements spaced about $10 \mathrm{~cm}$ apart [11]. These construction characteristics caused large thermal energy losses.

A comparison of U-values of the envelope in terms of construction period shows that the thermal characteristics deteriorated in the period from 1946 to 1965 compared to the period before 1945. This is due to the changes made in the construction of building elements of the envelope by reducing thickness of walls, introducing reinforced concrete and new construction technologies that make it possible to build faster, while ignoring thermal protection, which caused significantly poorer thermal characteristics. A consequence of this type of construction is the increased consumption of thermal energy and the appearance of moisture due to uninsulated thermal bridges.

In the periods from 1966 to 1973 and from 1974 to 1987, the first regulations related to the thermal protection of buildings were developed and applied, which to some extent led to an improvement of thermal characteristics of the envelope and to reduction of the required thermal energy. Buildings from this period are characterized by the emergence of thermalinsulating double glazing, however window frames are still without an uninterrupted thermal bridge. Buildings from this period are characterized by very fragmented architectural forms with a very poor shape factor, and large glass surfaces on exterior walls, which did not lead to significant improvement in the U-value of the overall envelope elements [11].

The period from 1988 to 2009 is characterized by a very low intensity of construction and a significant use of new materials in the period after 2000. Namely, a significant use of thermal insulation materials and windows with thermal insulating glazing and interrupted thermal bridges did not appear until after 2000. However, this was still happening spontaneously, without legal obligation, based only on the knowledge of investors and designers and their own need to reduce heating costs [11].

In 2010, for the first time, buildings began to be considered and calculated as single energy units. There is a significant influence of programs and projects of international organizations in the field of energy efficiency improvement on the dissemination of knowledge and awareness of the need and benefits of thermal protection of buildings. The construction and reconstruction of buildings with thermal characteristics significantly better than in buildings from previous construction periods are intensified in this period [11].

Finally, a comparison of the obtained U-values with the allowable values was carried out in order to determine the degree of their fulfillment as well as the quality of the envelope in the present condition. Table 6 gives the allowable U-values according to the Rules on technical requirements for thermal protection of buildings and rational use of energy from 2009 and according to the new Rules on minimum requirements for energy performance of buildings from 2019 , which has stricter requirements.

Table 6 Data on average U-values of building elements of the envelope of school buildings in $\mathrm{SR} \mathrm{FBiH}$ from the sample and the allowable values according to the books of rules

\begin{tabular}{|c|c|c|c|c|}
\hline No. & $\begin{array}{c}\text { Envelope } \\
\text { element }\end{array}$ & $\begin{array}{c}\text { Average } \\
\mathrm{U}-\text {-value } \\
\left(\mathrm{W} / \mathrm{m}^{2} \mathrm{~K}\right)\end{array}$ & $\begin{array}{c}\text { Rules 2009. [15] } \\
\mathrm{U}\left(\mathrm{W} / \mathrm{m}^{2} \mathrm{~K}\right) \text { for } \\
\Theta_{\mathrm{e}, \mathrm{mon}}>3^{\circ} \mathrm{C}\end{array}$ & $\begin{array}{c}\text { Rules 2019. [24] } \\
\mathrm{U}\left(\mathrm{W} / \mathrm{m}^{2} \mathrm{~K}\right) \text { for } \\
\Theta_{\mathrm{e}, \mathrm{mon}}>3^{\circ} \mathrm{C}\end{array}$ \\
\hline 1. & $\begin{array}{c}\text { External } \\
\text { walls }\end{array}$ & 1.55 & 0.60 & 0.45 \\
\hline 2. & Floors & 1.89 & 0.50 & 0.50 \\
\hline 3. & Ceilings & 1.90 & 0.40 & 0.30 \\
\hline 4. & Openings & 2.76 & 1.80 & 1.60 \\
\hline
\end{tabular}

where $\Theta_{e, \text { mon }}$ is the mean monthly temperature of the coldest month of the year. 
Katić, D., Krstić, H., Marenjak, S.

U-values of school building envelopes in the south region of the Federation of Bosnia an Herzegovina

In relation to the requirements from 2009 , the average U-values of walls are 2.58 times higher, of floors 3.78 , of ceilings 4.75 and of openings 1.53 times higher. U-values for the existing condition of building elements of the envelope exceed the allowable values several times, which is indicative of the absence of thermal insulation layers and leads to overall thermal transmission losses in maximum degree. In relation to the allowable values from 2019, the exceedances of U-values are even greater. Due to the aforementioned, the Uvalues of building elements of the envelope represent one of the essential features or character variables that have an effect on the consumption of thermal energy.

\section{CONCLUSION}

A statistical analysis of the characteristics of the envelope of school buildings in SR FBiH from the sample in relation to construction period was performed, and the following was determined:

- equal average share of the area of walls and ceilings in the total area of the envelope which is approximately $30.5 \%$, the share of the area of floors is approximately $27 \%$ and the share of openings approximately $12 \%$

- average $\mathrm{U}$-value for walls is $1.55 \mathrm{~W} / \mathrm{m}^{2} \mathrm{~K}$, for floors $1.89 \mathrm{~W} / \mathrm{m}^{2} \mathrm{~K}$, for ceilings 1.90 $\mathrm{W} / \mathrm{m}^{2} \mathrm{~K}$ and for openings $2.76 \mathrm{~W} / \mathrm{m}^{2} \mathrm{~K}$

- $\quad$ average $U$-value of the total envelope is $1.88 \mathrm{~W} / \mathrm{m}^{2} \mathrm{~K}$

- average U-values of individual elements of the envelope exceed the allowable values several times according to current regulations, which is indicative of the absence of thermal insulation layers.

The above-presented analysis results indicate very poor thermal characteristics of the existing condition of the envelope of school buildings in SR $\mathrm{FBiH}$, and measures for making thermal insulation of external walls, ceilings against attics, roofs or unheated spaces and for replacing external openings are anticipated in the planning of measures to improve the performance of building elements of the envelope

Measures to improve energy efficiency can be classified into categories according to energy, economic and environmental contribution. In terms of energy, this has the effect of reducing the need for thermal energy for heating (due to the reduction of heat losses) and the effect of reducing the cost of heating, or reducing operating costs (economic criterion). This also leads to a reduction in environmental impacts and a reduction in emissions of harmful gases.

\section{REFERENCES}

1. D. R. Luísa Dias Pereira, Stefano Paolo Corgnati, Manuel Gameiroda Silva, "Energy consumption in schools - A review paper," Renewable and Sustainable Energy Reviews, vol. 40, pp. 911-922, 2014. http://dx.doi.org/10.1016/j.rser.2014.08.010

2. F. AlFaris, A. Juaidi, and F. Manzano-Agugliaro, "Improvement of efficiency through an energy management program as a sustainable practice in schools," Journal of Cleaner Production, vol. 135, pp. 794-805, 2016.

3. S. A. Ghita, and T. Catalina, "Energy efficiency versus indoor environmental quality in differentRomanian countryside schools," Energy and Buildings, vol. 92, pp. 140-154, 2015. http://dx.doi.org/10.1016/j.enbuild.2015.01.049

4. B. Basarir, B. S. Diri, and C. Diri, "Energy efficient retrofit methods at the building envelopes of the school buildings," in Retrofit 2012, 2012. 
Katić, D., Krstić, H., Marenjak, S.

U-values of school building envelopes in the south region of the Federation of Bosnia an Herzegovina

5. L. F. Cabeza, Lídia Rincón, Virginia Vilariño et al., "Life cycle assessment (LCA) and life cycle energy analysis (LCEA) of buildings and the building sector: A review," Renewable and Sustainable Energy Reviews, vol. 29, pp. 394-416, 2014. http://dx.doi.org/10.1016/j.rser.2013.08.037

6. B. Nicolaea, and B. George-Vlad, "Life cycle analysis in refurbishment of the buildings as interventionpractices in energy saving," Energy and Buildings, 2014. http://dx.doi.org/10.1016/j.enbuild.2014.10.021

7. P. Zancanella, P. Bertoldi, and B. Boza-Kiss, Energy efficiency, the value of buildings and the payment default risk, Luxembourg, 2018.

8. R. Pacheco, J. Ordonez, and G. Martínez, "Energy efficient design of building: A review," Renewable and Sustainable Energy Reviews, vol. 16, pp. 3559-3573, 2012. 10.1016/j.rser.2012.03.045

9. R. S. Adhikari, E. Lucchi, and V. Pracchi, "Experimental measurements on thermal transmittance of the opaque vertical walls in the historical buildings."

10. G. K. Oral, and Z. Yilmaz, "The limit $U$ values for building envelope related to building form in temperate and cold climatic zones," Building and Environment, vol. 37, pp. 1173-1180, 2002.

11. M. Nišandžić, Tipologija javnih zgrada u Bosni i Hercegovini, Razvojni program Ujedinjenih nacija (UNDP) u Bosni i Hercegovini, 2018.

12. T. Babaei, H. Abdi, C. P. Lim et al., "A study and a directory of energy consumption data sets of buildings, Energy and Buildings," 2015.

13. Smjernice za provođenje energijskog pregleda za nove i postojeće objekte s jednostavnim i složenim tehničkim sistemom, Federalno ministarstvo prostornog uređenja, Sarajevo, 2009.

14. U. Desideri, D. Leonardi, L. Arcioni et al., "European project Educa-RUE: An example of energy efficiency paths in educational buildings," Applied Energy, vol. 97, pp. 384395, 2012. 10.1016/j.apenergy.2012.02.009

15. Pravilnik o tehničkim zahtjevima za toplinsku zaštitu objekata i racionalnu upotrebu energije (SI. novine $\mathrm{FBiH}$, br. 49/09), Federalno ministarstvo prostornog uređenja, Sarajevo, 2009.

16. Ž. Pauše, Uvod u matematičku statistiku: Školska knjiga Zagreb, 1993.

17. M. Papić, Primijenjena statistika u MS Excelu za ekonomiste, znanstvenike i neznalice, Zoro d.o.o., Zagreb, 2005.

18. A. H. Boussabaine, R. J. Kirkham, and R. J. Grew, "Modelling total energy costs of sport centres," Facilities, vol. 17, no. 12/13, pp. 452-461, 1999. http://dx.doi.org/10.1108/02632779910293442

19. P. Marrone, P. Gori, F. Asdrubali et al., "Energy Benchmarking in Educational Buildings through Cluster Analysis of Energy Retrofitting," Energies, vol. 11, 2018. doi:10.3390/en11030649

20. R. Ghedamsi, N. Settou, A. Gouareh et al., "Modeling and forecasting energy consumption for residential buildings in Algeria using bottom-up approach," Energy and Buildings, 2015. http://dx.doi.org/10.1016/j.enbuild.2015.12.030

21. I. Nardi, D. Paoletti, D. Ambrosini et al., "U-value assessment by infrared thermography: A comparison ofdifferent calculation methods in a Guarded Hot Box," Energy and Buildings, vol. 122, pp. 211-221, 2016. http://dx.doi.org/10.1016/j.enbuild.2016.04.017

22. G. Ficco, F. lannetta, E. lanniello et al., "U-value IN-SITU measurement for energy diagnosis of existing buildings, Energy and Buildings," 2015.

23. M. S. Vasov, J. N. Stevanović, V. B. Bogdanović et al., "Impact of Orientation and Building Envelope Characteristics on energy consumption, Case Study of Office 
Katić, D., Krstić, H., Marenjak, S.

$U$-values of school building envelopes in the south region of the Federation of Bosnia an Herzegovina

Building in City of Nis," THERMAL SCIENCE, vol. 22, pp. 1499-1509, 2018. https://doi.org/10.2298/TSCI18S5499V

24. Pravilnik o minimalnim zahtjevima za energetskim značajkama zgrada (SI. novine FBiH", br. 81/2019), Federalno ministarstvo prostornog uređenja, Sarajevo, 2019. 